\title{
Review of juxtaglomerular cell tumor with focus on pathobiological aspect
}

\author{
Naoto Kuroda ${ }^{1 *}$, Hiroko Gotoda ${ }^{2}$, Chisato Ohe ${ }^{3}$, Shuji Mikami ${ }^{4}$, Keiji Inoue $^{5}$, Yoji Nagashima ${ }^{6}$, Fredrik Petersson ${ }^{7}$, \\ Isabel Alvarado-Cabrero ${ }^{8}$, Chin-Chen Pan ${ }^{9}$, Ondrej Hes $^{10}$, Michal Michal ${ }^{10}$ and Zoran Gatalica ${ }^{11}$
}

\begin{abstract}
Juxtaglomerular cell tumor (JGCT) generally affects adolescents and young adults. The patients experience symptoms related to hypertension and hypokalemia due to renin-secretion by the tumor. Grossly, the tumor is well circumscribed with fibrous capsule and the cut surface shows yellow or gray-tan color with frequent hemorrhage. Histologically, the tumor is composed of monotonous polygonal cells with entrapped normal tubules. Immunohistochemically, tumor cells exhibit a positive reactivity for renin, vimentin and CD34. Ultrastructurally, neoplastic cells contain rhomboid-shaped renin protogranules. Genetically, losses of chromosomes 9 and 11 were frequently observed. Clinically, the majority of tumors showed a benign course, but rare tumors with vascular invasion or metastasis were reported. JGCT is a curable cause of hypertensive disease if it is discovered early and surgically removed, but may cause a fatal outcome usually by a cerebrovascular attack or may cause fetal demise in pregnancy. Additionally, pathologists and urologists need to recognize that this neoplasm in most cases pursues a benign course, but aggressive forms may develop in some cases.
\end{abstract}

\section{Introduction}

Juxtaglomerular cell tumor (JGCT) is a very rare cause of hypertension that was first described by Robertson et al. in 1967 and the name was coined by Kihara in 1968 [1,2]. To date, approximately 100 cases with JGCT have been reported. Clinically, this tumor is characterized by hypertension, hyperaldosteronism and hypokalemia secondary to excessive renin secretion by tumor cells [3-8]. In this article, we introduce the general overview of JGCT with focus on pathobiological aspects.

\section{Epidemiology}

This tumor affects adolescents and young adults, with peak prevalence in the second and third decades of life with a female predominance [8-10]. Haab et al. (1995) detected eight JGCTs among 30,000 patients at a hypertensive clinic [11].

\section{Clinical findings}

Patients with JGCT present with various symptoms including headaches, retinopathy, double vision, dizziness,

\footnotetext{
* Correspondence: kurochankochi@yahoo.co.jp

'Department of Diagnostic Pathology, Kochi Red Cross Hospital, Shin-

honmachi 2-13-51, Kochi City, Kochi 780-8562, Japan Full list of author information is available at the end of the article
}

nausea, vomiting, polyuria and proteinuria $[8,12]$. Most of these symptoms may be attributed to hypertension or hypokalemia. Clinically, JGCT is subdivided into three categories [13]. The typical variant, which accounts for the majority of JGCT, has characteristically high renin concentration, hyperaldosteronism, hypokalemia and hypertension $[4,5]$. Second most common presentation is the atypical variant showing hypertension with normal potassium level [8]. The third, non-functioning variant is very rare and is characterized by a normal blood pressure and normal potassium level [14-16]. Clinicians should strongly suspect JGCT if they encounter adolescent or young adult patients with severe or even moderate hypertension associated with an unexplained secondary hyperaldosteronism [6]. JGCT may cause malignant hypertension [17]. A case of JGCT associated with membranous glomerulonephritis was also reported [18].

\section{Radiological findings}

Ultrasonography of the kidneys usually shows a hypoechoic mass $[19,20]$. Computed tomography (CT) scan is very useful for the detection of renal tumor, even when other imaging analyses is negative $[8,21]$. CT scan shows finding of low, low-to iso- or low- to high-density without enhancement [20,22-24]. In dynamic CT scan, JGCT
C Biomed Central 
is not stained during early phase, but stains moderately during late phase after contrast enhancement [24-26]. Magnetic resonance imaging is also a powerful diagnostic procedure [12,23,25]. MRI shows an iso-signal intensity area on T1-weighted images and a high-signal intensity area on T2-weighted images, but MRI findings seem to variable $[23,26,27]$.

\section{Pathological findings \\ Macroscopic findings}

Grossly, the tumor is well circumscribed and complete or partial fibrous capsule is observed in most cases $[9,28]$. The cut surface of the tumor imparts yellow to gray-tan in color with frequent hemorrhage [9]. The tumor is usually small solitary and unilateral, but the tumors exceeding $3 \mathrm{~cm}$ are occasionally observed $[8,29,30]$. A case of extrarenal JGCT arising in bone has been reported [31].

\section{Microscopic findings}

Histologically, the tumor consists of solid sheets of closedly packed uniform round to polygonal cells with oval to round nuclei, pale to eosinophilic cytoplasm, inconspicuous nucleoli and indistinct cell border (Figure 1,2) [10]. Microcystic pattern is also seen [9,32,33]. Focal moderate nuclear atypia may be seen, but mitotic figures are generally absent [9]. Entrapped tubules are identified; predominantly at the peripheral area of the tumor but tubular cells suggestive of neoplastic nature has been reported $[28,29,34,35]$. Thin-wall and thick-wall blood vessels with hyalinization are intervened within the

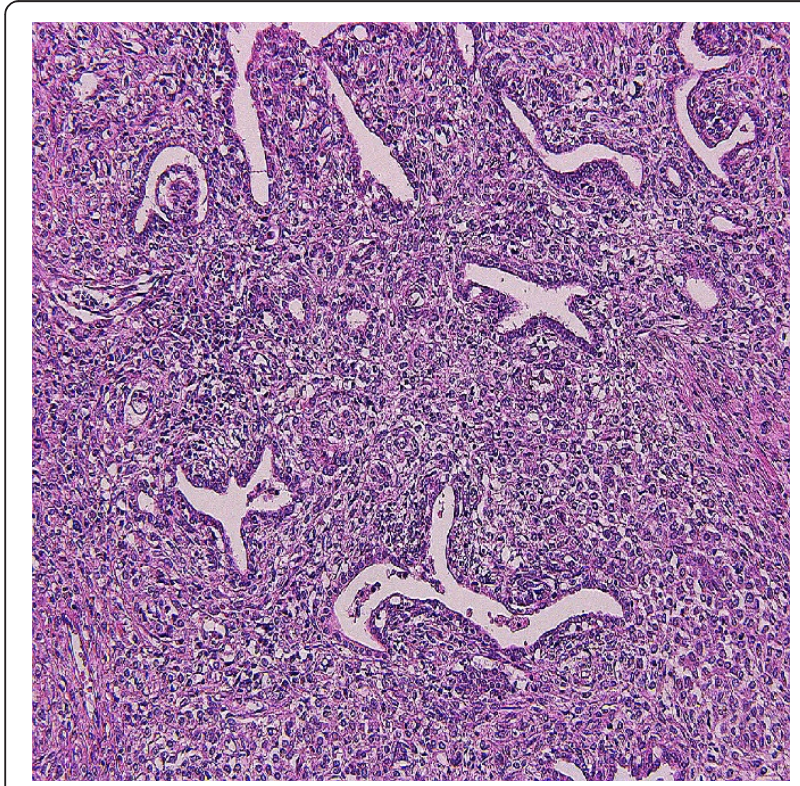

Figure 1 Microscopic findings. Low power view. Neoplastic cells with ovoid to polygonal in shape proliferate with growth pattern of solid sheets. Intervening tubular component is also seen.

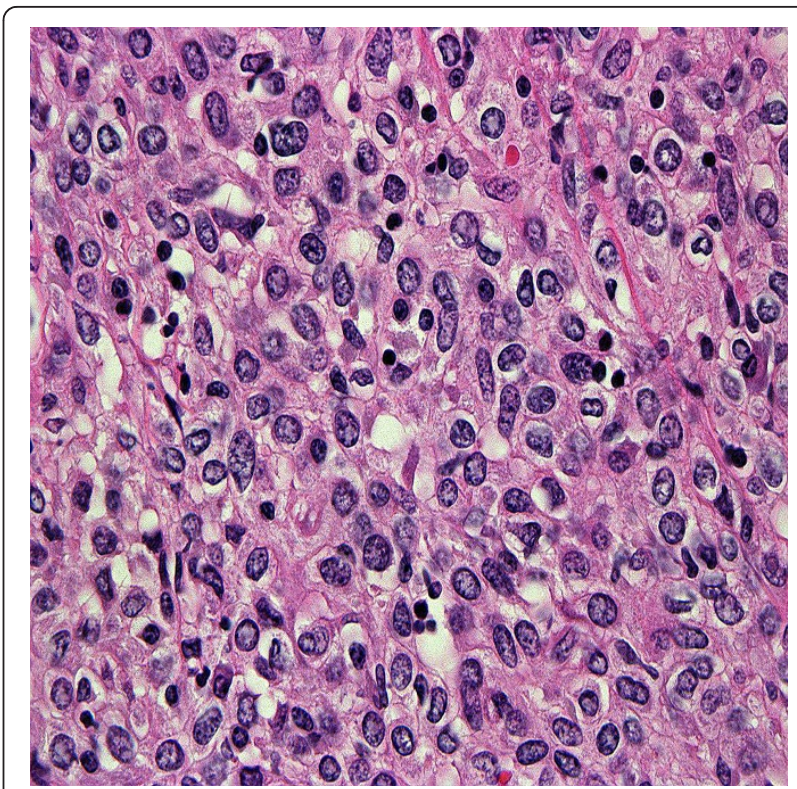

Figure 2 Microscopic findings. High power view. Cell border is generally indistinct and mitotic activity is absent. There is no or little pleomorphism of nuclei, but multinuclear cells are focally seen.

tumor and antler vascular pattern simulating hemangiopericytoma may be noted $[3,9,28,32,35]$. Mast cells often infiltrate in the stroma $[4,36]$. Penetration of fibrous capsule or vascular invasion by tumor cells may be observed in some cases [37-39] (Figure 3).

\section{Histochemical findings}

Intracytoplasmic granules suggestive of renin storage may be detected by Bowie, periodic acid-Aschiff, and

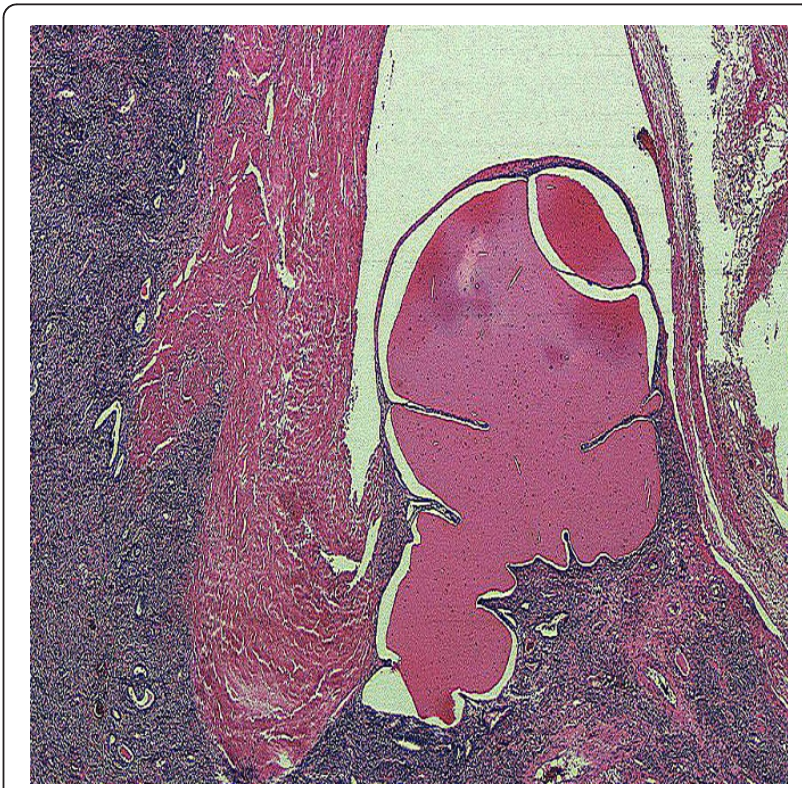

Figure $\mathbf{3}$ Microscopic findings. Vascular invasion is seen. 
phostotungstic acid-hematoxylin-azan stains [2-4,28, 29,40-42]. Toluidine blue stain is useful in the detection of mast cells in the stroma [43].

\section{Immunohistochemical findings}

The diagnosis is confirmed by positivity for renin in the cytoplasm $[12,21,22,34,35,42]$. However, renin positivity may be observed in some cases of Wilms tumor, RCC or renal oncocytoma [7]. Most neoplastic cells are diffusely immunoreactive for vimentin and CD34 [44] (Figure 4). The immunoreactivity to smooth muscle actin and CD117 varies from case to case $[9,10]$. Tumor cells demonstrate no reactivity to von Willebrand factor, CD31, desmin, S-100 protein, melanosome-related antigen, chromogranin A, synaptophysin, and neuron specific enolase $[9,35]$. Epithelial components are positive for cytokeratin CAM5.2 and cytokeratin 7 [35].

\section{In situ hybridization findings}

Messenger RNA of renin is found in the cytoplasm of tumor cells of JGCT. Some investigators suggest that renin synthesis and storage may be concordant [45], whereas others consider that the positivity of messenger RNA in the tumor cytoplasm may be due to uptake of renin rather than renin production [37].

\section{Ultrastructural findings}

The cytoplasm of tumor cells contains characteristic rhomboid-shaped renin protogranules, abundant rough endoplasmic reticulum and prominent Golgi apparatus $[4,9,10,22,29,34,40-42,44,46]$. Secretory granules of various size and shapes are also observed [36]. Micropinocytotic vesicles and submembranous plaques suggestive of smooth muscle differentiation may be also contained

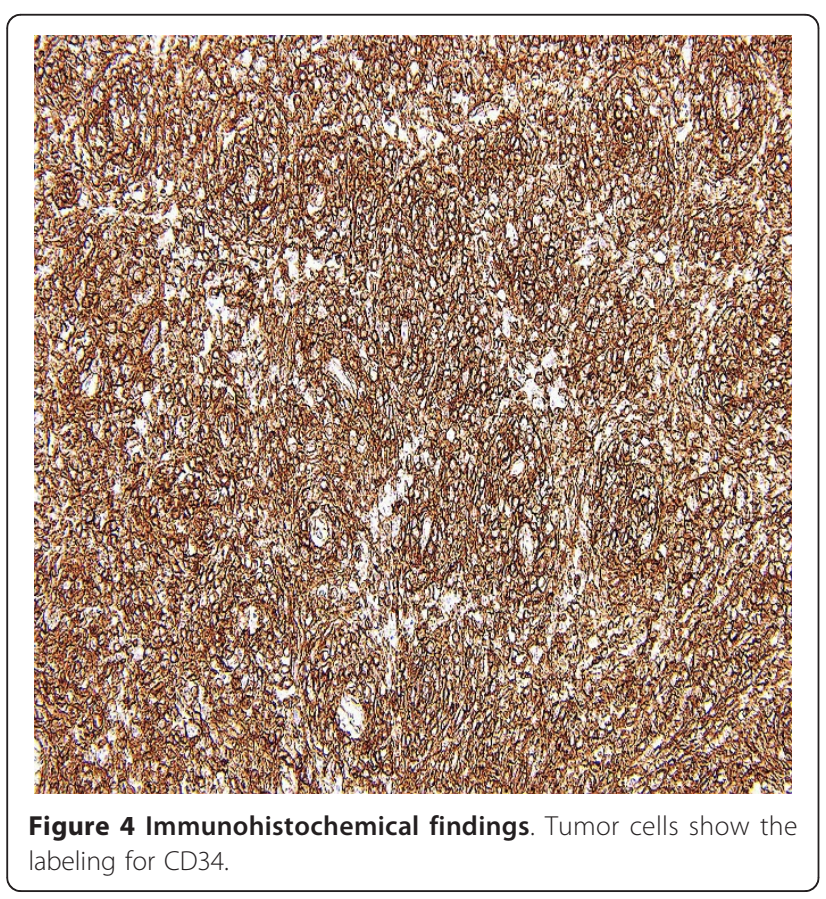

in the cytoplasm [32,47]. The presence of nerve fibers have been reported [48]. Ultrastructural immunocytochemistry showed that immunoreactive renin is observed not only in crystalline protogranules or round membrane bound granules but also in intermediate form [49].

\section{Differential Diagnosis}

The distinction from glomus tumor, hemangiopericytoma, metanephric adenoma, papillary RCC, collecting duct carcinoma (CDC), urothelial carcinoma (UC), renal epithelioid angiomyolipoma (AML) and Wilms tumor should be considered. JGCT may possess the growth pattern reminiscent of glomus tumor. However, glomus tumor contains no epithelial component and is immunohistochemically negative for renin. Hemangiopericytoma lacks polygonal cells and thick-walled vessels. Solitary fibrous tumor often shows the hemangiopericytomatous pattern, but this tumor is frequently reactive for CD99 and bcl-2. JGCT with prominent papillary growth pattern may resemble papillary RCC [35]. However, papillary RCC lacks biphasic pattern of round to polygonal cells and epithelial cells. Metanephric cells typically show acinar growth pattern and psammoma bodies are often seen in the stroma. Solid sheets growth pattern of JGCT may evoke the diagnosis of CDC or poorly differentiated UC. However, CDC or urothelial carcinoma is macroscopically located in the renal medulla or hilar region, respectively, but the location of many JGCTs is the renal cortex. Renal angiomyolipoma may contain minor adipose tissue component and show the immunoreactivity for melanosome-related antigen. Wilms' tumor typically contains blastemal cells showing nuclear overlapping.

\section{Molecular genetic findings}

There are only a few limited reports on genetic abnormalities of JGCT. Using karyotype, comparative genomic hybridization $(\mathrm{CGH})$ and interphase fluorescence in situ hybridization (FISH), the gain of chromosome 10 as well as losses of chromosomes 9 and $\mathrm{X}$ and most of chromosome 11q may be important pathogenetic events in JGCT [50]. One case demonstrated monosomy of chromosomes $\mathrm{X}, 6,9,11,15$ and 21 using FISH analysis [51]. Two tumors revealed losses of chromosomes 9 and 11 by CGH [52]. Aneuploid karyotype and complex genomic imbalance observed in two cases may reflect a possible development for local recurrence or distant metastasis, namely uncertain malignant potential [50,52].

\section{Therapy}

The complete tumor resection by radical or partial nephrectomy is the best modality for JGCT [35,53]. Antihypertensive agents should be treated for hypertension until accurate diagnosis is made, but blood pressure, 
plasma renin level usually normalize after the nephrectomy in most cases with JGCT [2,23,25,54-56]. However, hypertension may continue because of hypertensive angiopathy even after the complete tumor removal in approximately $10 \%$ of all cases $[10,25,47]$.

\section{Prognosis}

The majority of cases with JGCT have behaved in a benign manner and neither local recurrence nor metastasis has occurred with either radical or partial nephrectomy. However, one metastatic case with JGCT has been reported to date [38]. Additionally, a case of JGCT that caused death due to massive brain hemorrhage secondary to severe hypertension has been reported [57]. A case of JGCT causing fetal demise has been noted [58].

\section{Conclusion}

Since the discovery of this tumor approximately 40 years ago, many common histological features including histochemistry, immunohistochemistry and ultrastructure have been elucidated and, as a result, JGCT gained the status as the distinct mesenchymal tumor entity from other renal tumor. However, there are only a few genetic studies of JGCT because of the rarity of this disease. As we encountered a case of JGCT with vascular invasion, the true biological behavior of JGCT will be needed to be elucidated. Accordingly, genetic features of JGCT need to be clarified by the future investigations.

\begin{abstract}
Author details
1Department of Diagnostic Pathology, Kochi Red Cross Hospital, Shinhonmachi 2-13-51, Kochi City, Kochi 780-8562, Japan. ²Department of Pathology, Sapporo Kosei General Hospital, 8-5 Kita 3-jo Higashi, Sapporo, Hokkaido 060-0033, Japan. ${ }^{3}$ Department of Pathology, Kansai Medical University, Hirakata Hospital, 2-3-1 Shinmachi, Hirakata, Osaka 573-1191, Japan. ${ }^{4}$ Division of Diagnostic Pathology, Keio University Hospital, 35 Shinanomachi, Shinjuku-ku, Tokyo 160-8252, Japan. ${ }^{5}$ Department of Urology, Kochi Medical School, Kochi University, Kohasu, Oko-cho, Nankoku City, Kochi 783-8505, Japan. ${ }^{6}$ Department of Molecular Pathology, Yokohama City University Graduate School of Medicine, B252, 3-9 Fukuura, Kanazawa-ku, Yokohama City, Kanagawa 236-0004, Japan. ${ }^{7}$ Department of Pathology, National University Hospital System, 119074 Singapore, Singapore. ${ }^{8}$ Department of Pathology, Mexican Oncology Hospital, Instututo Mexicano del Seguro Social, Mexico City, Mexico. ${ }^{9}$ Taipei Veterans General Hospital, No.201, Shi-Pai Rd. Sec2, Taipei 11217, Taiwan. ${ }^{10}$ Sikl's Department of Pathology, Charles University Hospital PIzen, Alej Svobody 80, 30460 PIzen, Czech Republic. " Depertment of Pathology, Creighton University School, Omaha, NE 68131, USA.
\end{abstract}

\section{Authors' contributions}

NK, HG, SM and YN describe pathological findings, KI write epidemiology and clinical findings, FP, IAC and CCP describe molecular genetic findings, and $\mathrm{CO}, \mathrm{OH}, \mathrm{MM}$ and $\mathrm{ZG}$ revise the manuscript. All authors read and approved the final manuscript.

\section{Competing interests}

The authors declare that they have no competing interests.

Received: 10 June 2011 Accepted: 26 August 2011

Published: 26 August 2011
References

1. Robertson PW, Klidijan A, Harding LK, Walters G, Lee MR, Robb-Smith AHT: Hypertension due to a renin-secreting renal tumor. Am J Med 1967, 43(6):963-976.

2. Kihara I, Kitamura S, Hoshino $T$, Sieda H, Watanabe T: A hitherto unreported vascular tumor of the kidney: A proposal of "juxtaglomerular cell tumor". Acta Path Jap 1968, 18(2):197-206.

3. Eddy RL, Sanchez SA: Renin-secreting renal neoplasm and hypertension with hypokalemia. Ann Int Med 1971, 75(5):725-729.

4. More IA, Jackson AM, MacSween RNM: Renin-secreting tumor associated with hypertension. Cancer 1974, 34(6):2093-2102.

5. Valdes G, Lopez JM, Maritinez P, Rosenberg H, Barriga P, Rodriguez JA, Otipka N: Renin-secreting tumor. Case report. Hypertension 1980, 2(5):714-718

6. Baruch D, Corvol P, Alhenc-Celas F, Dukloux M-A, Guyenne TT, Gauz J-C, Raynaud A, Brisset J-M, Duclos J-M, Menard J: Diagnosis and treatment of renin-secreting tumors. Report of three cases. Hypertension 1984, 6(5):760-766.

7. Tomita T, Posner A, Inagami T: Immunohistochemical localization of renin in renal tumors. Am J Pathol 1987, 126(1):73-80.

8. McVicar M, Carman C, Chandra M, Abbi RJ, Teichberg S, Kahn E: Hypertension secretory to renin-secreting juxtaglomerular cell tumor: case report and review of 38 cases. Pediatr Nephrol 1993, 7(4):404-412.

9. Martin SA, Mynderse LA, Lager DJ, Cheville JC: Juxtaglomerular cell tumor. A clinicopathologic study of four cases and review of the literature. Am J Clin Pathol 2001, 116(6):854-863.

10. Kim H-J, Kim CH, Choi Y-J, Ayala AG, Amirikachi M, Ro JY: Juxtaglomerular cell tumor of kidney with CD34 and CD117 immunoreactivity. Report of 5 cases. Arch Pathol Lab Med 2006, 130(5):707-711.

11. Haab F, Dulcos JM, Guyenne T, Plouin PF, Corvol P: Renin-secreting tumors: diagnosis, conservative surgical approach and long-term results. J Urol 1995, 153(6):1781-1784

12. Agrawal R, Zafar S, Jafri H, Gibson DP, Bis KG, Al-Reza A: Juxtaglomerular cell tumor: MR findings. J Comput Assist Tomogr 1995, 19(1):140-142.

13. Dong D, Li H, Yan W, Xu W: Juxtaglomerular cell tumor of the kidney-a new classification schema. Urol Oncol 2010, 28(1):34-38.

14. Kihara I: Comments on different states of secretory autonomy of juxtaglomerular cell tumors of the kidney. Int Med 1996, 35(4):239-240.

15. Endoh Y, Motoyama T, Hayami S, Kihara I: Juxtaglomerular cell tumor of the kidney: report of a non-functioning variant. Pathol Int 1997, 47(6):393-396

16. Hayami S, Sasagawa I, Suzuki H, Kubota Y, Nakada T, Endo Y: Juxtaglomerular cell tumor without hypertension. Scand J Urol Nephrol 1998, 32(3):231-233.

17. Liborio AB, Marques Fde $O$, Testagrosse L, Leite CA, Leitao AA, Praxedes JN: Malignant hypertension with intestinal ischemia second to juxtaglomerular cell tumor. Am J Kid Dis 2005, 46(5):957-961.

18. Ng SB, Tan PH, Chuah KL, Cheng CC, Tan J: A case of juxtaglomerular cell tumor associated with membranous glomerulonephritis. Ann Diagn Pathol 2003, 7(5):314-320

19. Merte UK, Niranjan J, Kusum J, Rajesh LS, Goswami AK, Sharma SK: Reninoma treated with nephron-sparing surgery. Urology 2003, 61(6):1259-1260

20. Gottardo F, Cesari M, Morra A, Gardiman M, Fassina A, Dal Bianco M: A kidney in an adolescent with severe hypertension and hypokalemia: an uncommon case-case report and review of the literature on reninoma. Urol Int 2010, 85(1):121-124.

21. Caregaro L, Menon F, Gatta A, Amodio P, Armanini D, Fallo F, Corona MC, Pescarini L, Ruol A: Juxtaglomerular cell tumor of the kidney. Clin Exper Hypertens 1994, 16(1):41-53.

22. Schonfeld AD, Jackson JA, Somerville SP, Johnson CF, Anderson PW: Reninsecreting juxtaglomerular cell tumor causing severe hypertension: Diagnosis by computerized tomography-directed needle biopsy. J Urol 1991, 146(6):1607-1609

23. Tanabe A, Naruse $K$, Kono A, Hase M, Hashimoto $Y$, Nakazawa $H$, Naruse $M$, Demura $\mathrm{R}$, Demura $\mathrm{H}$, Toma $\mathrm{H}$ : A very small juxtaglomerular cell tumor preoperatively identified by magnetic resonance imaging. Int Med 1996, 35(4):295-300

24. Tanabe A, Naruse M, Ogawa T, Ito F, Takagi S, Takano K, Ohashi H, Tsuchiya K, Sone M, Nihei H, Toma H: Dynamic computer tomography is 
useful in the differential diagnosis of juxtaglomerular cell tumor and renal cell carcinoma. Hypertens Res 2001, 24(4):331-336.

25. Rubenstein JN, Eggener SE, Pins MR, Rosner K, Chugh S, Campbell SC: Juxtaglomerular apparatus tumor: A rare, surgically correctable cause of hypertension. Rev Urol 2002, 4(4):192-195.

26. Katabathina VS, Vikram R, Nagar AM, Tamboli P, Menias CO, Prasad SR: Mesenchymal neoplasms of the kidney in adults: Imaging spectrum with radiologic-pathologic correlation. Radiographics 2010, 30(6):1525-1540.

27. Watanabe M, Sugi M, Murota T, Kawakita M, Sakaida N, Okamura A, Matsuda T: Retroperitoneoscopic nephrectomy for juxtaglomerular cell tumor. Int J Urol 2002, 9(12):704-706.

28. Furusato M, Hayashi H, Kawaguchi N, Yokota K, Saito K, Aizawa S, Ishikawa E: Juxtaglomerular cell tumor with special reference to the tubular component in regards to its histogenesis. Acta Pathol Jpn 1983, 33(3):609-618.

29. Abbi RK, McVicar M, Teichberg S, Fish L, Kahn E: Pathologic characterization of a renin-secreting juxtaglomerular cell tumor in a child and review of the pediatric literature. Pediatr Pathol 1993, 13(4):443-451.

30. Tamboli P, Ro JY, Amin MB, Ligato S, Ayala AG: Benign tumors and tumorlike lesions of the adult kidney Part II: Benign mesenchymal and mixed neoplasms, and tumor-like lesions. Adv Anat Pathol 2000, 7(1):47-66.

31. Chen WS, Chang JW: Extrarenal juxtaglomerular cell tumor in bone. Chin Med J 1987, 100(1):78-82.

32. Kuten A, Olumi A, Goldsmith J, Monahan-Earley RA, Dvorak AM, Genega EM: Pathologic Quiz Case. A symptomatic renal tumor. Arch Pathol Lab Med 2004, 128(9):e112-e114.

33. Markey RB, MacLennan GT: Juxtaglomerular cell tumor of the kidney. J Urol 2006, 175(2):730..

34. Tanaka T, Okumura A, Mori H: Juxtaglomerular cell tumor. Arch Pathol Lab Med 1993, 117(11):1161-1164.

35. Tetu B, Vaillancourt L, Camilleri J-P, Bruneval P, Bernier L, Touriginy R: Juxtaglomerular cell tumor of the kidney: report of two cases with a papillary pattern. Hum Pathol 1993, 24(11):168-1174

36. Hasegawa A: Juxtaglomerular cell tumor of the kidney: A case report with electron microscopic and flow cytometric investigation. Ultrastruct Pathol 1997, 21(2):201-208.

37. Kodet R, Taylor M, Vachalova H, Pycha K: Juxtaglomerular cell tumor: An immunohistochemical, electron-microscopic, and in situ hybridization study. Am J Surg Pathol 1994, 18(8):837-842.

38. Duan X, Bruneval P, Hammadeh R, Fresco R, Eble JN, Clark J, Vigneswaran WT, Flanigan RC, Pickman MN: Metastatic juxtaglomerular cell tumor in a 52-year old man. Am J Surg Pathol 2004, 28(8):1098-1102.

39. Beaudoin J, Perigny M, Tetu B, Lebel M: A patient with a juxtaglomerular cell tumor with histological vascular invasion. Nat Clin Pract Nephrol 2008, 4(8):458-462.

40. Hanna W, Tepperman J, Logan AG, Robinette MA, Colapinto R, Phillips MJ: Juxtaglomerular cell tumor (reninoma) with paroxysmal hypertension. Can Med Assoc J 1979, 120(8):957-959.

41. Lopez G-Asenjo JA, Blanco Gonzalez J, Ortega Medina L, Sanz Esponera J: Juxtaglomerular cell tumor of the kidney: Morphological, immunohistochemical and ultrastructural studies of a new case. Path Res Pract 1991, 187(2-3):354-359.

42. Min KO, Kwon HJ, Ahn SJ, Chang SA, Chang YS, Bang BK, Kim J, Park MH, Jung ES, Choi YJ, Seo EJ, Kim BK: Juxtaglomerular cell tumor of the kidney: A case report. J Korean Med Sci 2001, 16(2):233-236.

43. Dennis RL, MCDougal WS, Glick AD, MacDonell RC: Juxtaglomerular cell tumor of the kidney. J Urol 1985, 134(2):334-338.

44. Beevers DG, Mahesshwari MB, Ryan PG, Moss MS, Harding LK: Hypertension due to a renin-secreting juxtaglomerular cell tumor. Am J Hypertension 2008, 21(12):1359-1361.

45. Bruneval P, Fournier J-G, Soubrier F, Belair M-F, Silva J-L, Guetier C, Pinet F, Tardivel I, Corvol P, Bariety J, Camilleri J-P: Detection and localization of renin messenger RNA in human pathologic tissues using in situ hybridization. Am J Pathol 1988, 131(2):320-330

46. Sanfilippo F, Pizzo SV, Croker BP: Immunohistochemical studies of cell differentiation in a juxtaglomerular cell tumor. Arch Pathol Lab Med 1982, 106(12):604-607.

47. Squires JP, Ulbright TM, DeSchryver-Kecskemeti K, Engleman W: Juxtaglomerular cell tumor of the kidney. Cancer 1984, 53(3):516-523.
48. Barajas L, Bennett CM, Connor G, Lindstrom RR: Structure of a juxtaglomerular cell tumor: The presence of a neural component. A light and electron microscopic study. Lab Invest 1977, 37(4):357-368.

49. Lindrop GBM, Stewart JA, Downie TT: The immunocytochemical demonstration of renin in a juxtaglomerular cell tumour by light and electron microscopy. Histopathology 1983, 7(3):421-431.

50. Brandal P, Busund L-T, Heim S: Chromosome abnormalities in juxtaglomerular cell tumors. Cancer 2005, 104(3):504-510.

51. Shao L, Manalang M, Cooley L: Juxtaglomerular cell tumor in an 8-yearold girl. Pediatr Blood Cancer 2008, 50(2):406-409.

52. Capovilla M, Couturier J, Molinie V, Amsellem-Oquazana D, Priollet $P$, Baumert $H$, Bruneval P, Vieillefond A: Loss of chromosomes 9 and 11 may be recurrent chromosomal imbalances in juxtaglomerular cell tumors. Hum Pathol 2008, 39(3):459-462.

53. Dong D, Li H, Yan W, Xu W, Lu L, Zeng Z: The diagnosis and surgical management of juxtaglomerular cell tumor of the kidney. $J$ Hypertens 2010, 28(3):628-632.

54. Moss AH, Peterson L, Scott W, Winter K, Olin DB, Garber RL: Delayed diagnosis of juxtaglomerular cell tumor hypertension. NCMJ 1982, 43(10):705-707.

55. Chambo JL, Junior RF, Lucon AM: Juxtaglomerular cell tumor as a rare cause of hypertension in adults. Int Braz J Urol 2004, 30(2):119-120.

56. Lin S-Y, Liu W-Y, Chen W-C, Chen R-H: Secondary hypertension due to a renin-secreting juxtaglomerular cell tumor. J Formos Med Assoc 2010, 109(3):237-240.

57. Gherardi GJ, Arya S, Hickler RB: Juxtaglomerular body tumor: A rare occult but curable cause of lethal hypertension. Hum Pathol 1974, 5(2):236-240.

58. Lachvac L, Svajdler M, Valansky L, Nagy V, Benicky M, Frohlichova L, Nyitrayova O: Juxtaglomerular cell tumor, causing fetal demise. Int Urol Nephrol 2010, 43(2):365-370.

doi:10.1186/1746-1596-6-80

Cite this article as: Kuroda et al:: Review of juxtaglomerular cell tumor with focus on pathobiological aspect. Diagnostic Pathology 2011 6:80.

\section{Submit your next manuscript to BioMed Central and take full advantage of:}

- Convenient online submission

- Thorough peer review

- No space constraints or color figure charges

- Immediate publication on acceptance

- Inclusion in PubMed, CAS, Scopus and Google Scholar

- Research which is freely available for redistribution 